\title{
Gilles Banderier, Des livres de Louis Guillaume de Montlor, baron de Modène
}

\section{Filippo Fonio}

\section{Q OpenEdition}

1 Journals

\section{Edizione digitale}

URL: http://journals.openedition.org/studifrancesi/35972

DOI: 10.4000/studifrancesi.35972

ISSN: 2421-5856

\section{Editore}

Rosenberg \& Sellier

\section{Edizione cartacea}

Data di pubblicazione: 1 juillet 2005

Paginazione: 151-152

ISSN: 0039-2944

\section{Notizia bibliografica digitale}

Filippo Fonio, «Gilles Banderier, Des livres de Louis Guillaume de Montlor, baron de Modène», Studi Francesi [Online], 145 (XLIX | I) | 2005, online dal 30 novembre 2015, consultato il 19 avril 2021. URL: http://journals.openedition.org/studifrancesi/35972 ; DOI: https://doi.org/10.4000/studifrancesi. 35972

Questo documento è stato generato automaticamente il 19 avril 2021.

\section{(c) (1)}

Studi Francesi è distribuita con Licenza Creative Commons Attribuzione - Non commerciale - Non opere derivate 4.0 Internazionale. 


\title{
Gilles Banderier, Des livres de Louis Guillaume de Montlor, baron de Modène
}

\author{
Filippo Fonio
}

\section{NOTIZIA}

GILLES BANDERIER, Des livres de Louis Guillaume de Montlor, baron de Modène, «Bibliothèque d'Humanisme et Renaissance», LXVI, 1 (2004), pp. 111-116.

1 Il ms. 2311 conservato presso la Bibliothèque municipale d'Avignone contiene una lista denominata nel Catalogue général des manuscrits des bibliothèques publiques de France della fine del XIX sec. "le livre de raison de G. de Modène, bailli de Montlor (1600-1610)". Si deve supporre che l'indicazione cronologica si riferisca soltanto a un'iscrizione contenuta nei fogli qui presi in esame, risalente ai primi anni del XVII sec., mentre la lista di libri sarebbe della seconda metà del Cinquecento. I volumi di cui consta la lista sono diciassette - non pochi in rapporto agli inventari delle biblioteche dell'epoca, tanto più che si tratta in questo caso di un alto funzionario e non di un erudito né di un letterato. La lista è probabilmente autografa e non redatta a cura di un notaio, anche in relazione agli scarsi dettagli forniti. La biblioteca del barone di Montlor era composta di autori classici utili per un membro della classe dirigente - Cicerone, Tacito, Seneca, ma anche di volumi che testimoniano un interesse per le controversie religiose dell'epoca (Panigarola, Antonio de Guevara, Jean Garet). 